\title{
Three new species of Sloanea L. (Elaeocarpaceae) from the Central Amazon, Brazil ${ }^{1}$
}

\author{
AMANDA SHIRLÉIA PINHEIRO BOEIRA ${ }^{2,5}$, ALBERTO VICENTINI ${ }^{3}$ and \\ JOSÉ EDUARDO LAHOZ DA SILVA RIBEIRO ${ }^{4}$
}

(received: November 3, 2011; accepted: February 16, 2012)

\begin{abstract}
Three new species of Sloanea L. (Elaeocarpaceae) from the Central Amazon, Brazil). Three new species of Sloanea L. are recognized based on specimens collected in the Adolpho Ducke Forest Reserve. These new species are morphologically distinct from other Sloanea in the Neotropics in terms of their vegetative and reproductive characters. The Ducke Reserve contains a total of 18 species of Sloanea, and the species closest to these new taxa occur there. Morphological descriptions and illustrations are provided, together with comments concerning morphological similarities with other species, as well as their geographic distributions and their phenologies.
\end{abstract}

Key words - characters, Ducke Forest Reserve, floristic survey, morphology, taxonomy

\section{INTRODUCTION}

The family Elaeocarpaceae comprises 15 genera and approximately 500 species (Crayn et al. 2006, Heywood 2007). Sloanea Linnaeu is the second largest genera with approximately 180 species distributed throughout the tropics and subtropics, with the exception of the African continent (Smith 1954). According to the identification guide of the Adolpho Ducke Forest Reserve (Vicentini 1999), the family Elaeocarpaceae is represented there by 17 species of the genus Sloanea, although four could not be identified to the species level. A detailed study of the vegetative and reproductive morphology of 132 specimens of Sloanea available for this Reserve indicated the existence of four species that had not yet been described, as well as one additional species, Sloanea laurifolia (Benth.) Benth. (Boeira 2010). Of the four species not identified by Vicentini (1999), one of them is probably an undescribed species similar to $S$. latifolia (Rich.) K. Schum, but as it has never been collected in a fertile state it has not been possible to make detailed comparisons of this morphology with the other species of Sloanea. The present study presents the descriptions of three new species of Sloanea occurring in the Adolpho

1. Part of the master's dissertation of the first author, Programa de Pós-Graduação em Botânica, Instituto Nacional de Pesquisas da Amazônia, AM, Brazil.

2. Instituto Nacional de Pesquisas da Amazônia. Av. André Araújo 2636, 60060-001 Manaus, AM, Brazil

3. Instituto Nacional de Pesquisas da Amazônia, Coordenação de Dinâmica Ambiental (CDAM), Av. André Araújo 2636, 60060-001 Manaus, AM, Brazil

4. Universidade Estadual de Londrina, Centro de Ciências Biológicas/ Departamento de Biologia Animal e Vegetal, Caixa Postal 6001, 86051-990 Londrina, PR, Brazil

5. Corresponding author: bioamandinha@gmail.com
Ducke Forest Reserve that are morphologically similar to and possibly related to other species that occur in the same reserve. We present descriptions with commentaries concerning the morphologically similar species as well as their differences.

\section{MATERIAL AND METHODS}

We examined herbarium specimens of the genus Sloanea prepared during the Projeto Flora (PFRD) floristic survey of the Ducke Reserve (Ribeiro et al. 1999) and currently deposited in the INPA herbarium. The Ducke Reserve occupies an area of $100 \mathrm{~km}^{2}$ and is located near the city of Manaus, in the central Brazilian Amazon. This area is at the intersection of a number of different phyto-geographical regions of the Amazon, and has large numbers of closely related species as well as a very high biodiversity (Oliveira \& Daly 1999).

The reproductive structures of the herbarium samples were rehydrated and the details of their morphological structures were examined using a stereomicroscope. The quantitative characters included in the descriptions were measured using digital calipers. A number of structures important to the identification of the species were illustrated with the aid of a camera lucida apparatus coupled to the stereomicroscope. The characters related to leaf architecture, such as the shape of the blade, the apex, base, leaf margins, and the details of the secondary and tertiary leaf venation followed the definitions proposed by the Leaf Architecture Working Group (1999). Data concerning the plant habits and the colors of the floral parts were derived from the sample labels and in situ observations.

The species descriptions summarize the data of the specimens measured. As such, instead of indicating only the amplitude of the variations as is normally done in taxonomic descriptions, we have included the averages and standard deviations of the values encountered for all quantitative 
characters; we have also indicated numbers of observations of each categorical characters. For example, "leaves alternate $(n=15)$ or opposite $(n=1), \mathrm{A}-(\mathrm{C} \pm \mathrm{D})-\mathrm{B} \mathrm{mm}$ long $(n=10)$ ", where $n$ is the number of specimens, $\mathrm{A}$ and $\mathrm{B}$ are the minimum and maximum values of leaf length respectively, $\mathrm{C}$ is the average of these values, and $\mathrm{D}$ the standard error.

\section{RESULTS AND DISCUSSION}

Sloanea dubia Boeira sp. nov. Tipo: BRAZIL. AmazonAs: Manaus, Adolpho Ducke Forest Reserve, X-1997, MR Mesquita et al. 19 (Holótipo: INPA).

Figures 1-3

Species S. brachytepala affinis, autem differt petiolis dense pubescentibus, longitude antherrum filamentis longiore et filamentibus dense pubescentibus

Tree 20-30 m tall, DBH 35-40 cm; alburnum darkyellow, odorless, sap translucent; live bark orangish to reddish, $5 \mathrm{~mm}$ thick; rhytidome gray-brown with barely prominent transversal lines; lenticels circular to elliptical, grouped vertically. Leaves alternate, 16$(18.5 \pm 1)-21 \mathrm{~cm}$ long, not grouped at the apex of the branch; stipules deciduous; petiole 3.0-(3.5 \pm 1$)-4.5 \mathrm{~cm}$ long, densely pubescent $(n=6)$; lamina elliptical $(n=3)$ or oval $(n=4), 57-(78 \pm 1)-111 \mathrm{~mm}$ wide, base rounded $(n=6)$, apex acuminate $(n=7)$, adaxial surface sparsely pubescent $(n=6)$, abaxial surface sparsely pubescent $(n=6)$, margin entire $(n=6)$; secondary venation brochidodromous, average of 15 pairs of secondary veins, tertiary veins percurrent $(n=6)$. Midrib impressed $(n=6)$, sparsely pubescent on adaxial and abaxial faces. Inflorescence axillar, 18-(28 \pm 1$)-43 \mathrm{~mm}$ long, peduncle 8.0-(12 \pm 1$)-16 \mathrm{~mm}$ long, pedicel 7-(13.5 \pm 1$)-20 \mathrm{~mm}$ long, width less than the receptacle. Flowers greenishwhite, slight odor, 3 per inflorescence; $4-(4 \pm 0.01)-5$ tepals, 5.5-(6.2 \pm 1$)-7.5 \mathrm{~mm}$ long, 3-(4 \pm 1$)-6 \mathrm{~mm}$ wide at base; staminoids absent; anther 1.5-(1.8 \pm 1$)-2 \mathrm{~mm}$ long, densely pubescent, longitudinally dehiscent; connective extends to a sharp point $0.1-(0.1 \pm 0.01)-0.2 \mathrm{~mm}$ long, densely pubescent; filament 1.3-(2.1 \pm 1$)-3.2 \mathrm{~mm}$ long, densely pubescent $(n=3)$; ovary 1.0-(1.5 \pm 0.1$)-2.0 \mathrm{~mm}$ wide, densely pubescent; 4-(4)-5 locules; style 2.0(3.5 \pm 1$)-6.6 \mathrm{~mm}$ long, 4-(4)-5 lobbed at apex. Fruits 3.0(3.3 \pm 0.1$)-3.7 \mathrm{~cm}$ long, without spines; 1 seed per fruit, aril red $(n=1)$. Occurs on sandy-clayish $(n=2)$, sandy $(n=2)$, or clayish $(n=2)$ soils in the Ducke Reserve.

Material examined: BRAZIL. Amazonas: Manaus, Reserva Florestal Ducke, 16-II-1998, PACL Assunção et al. 788 (INPA); Reserva Florestal Ducke, 07-X-1997, MAD de Souza et al. 426 (INPA); Reserva Florestal Ducke, 02-XII-1997, PACL Assunção et al. 737 (INPA);
Reserva Florestal Ducke, 01-X-1997, MR Mesquita et al. 19 (INPA); Reserva Florestal Ducke, 03-IV-1997, MAS Costa et al. 768 (INPA); Reserva Florestal Ducke, 31-III-1998, PACL Assunção et al. 1952 (INPA).

Vicentini (1999) recognized Sloanea dubia as a species very similar and closely related to $S$. brachytepala. Although they are very similar, there are obvious morphological differences between them and, as they both occur sympatrically in the Ducke Reserve, S. dubia and S. brachytepala appear to represent two distinct species. These two species are vegetatively similar in terms of: leaf shape - elliptical; leaf blade apex - acuminate; type of venation - brochidodromous; phyllotaxis - alternate. There are, however, clear morphological differences between them: (1) the petiole and the midrib on the abaxial surface are densely pubescent in $S$. dubia while in $S$. brachytepala these same structures are sparsely pubescent; (2) the leaves of $S$. brachytepala are grouped at the branch apex, in contrast to $S$. dubia where the leaves are not grouped; (3) the stamen filaments are twice the length of the anthers in $S$. brachytepala, while in $S$. dubia the anthers are very nearly the same length as the filaments; (4) the anthers

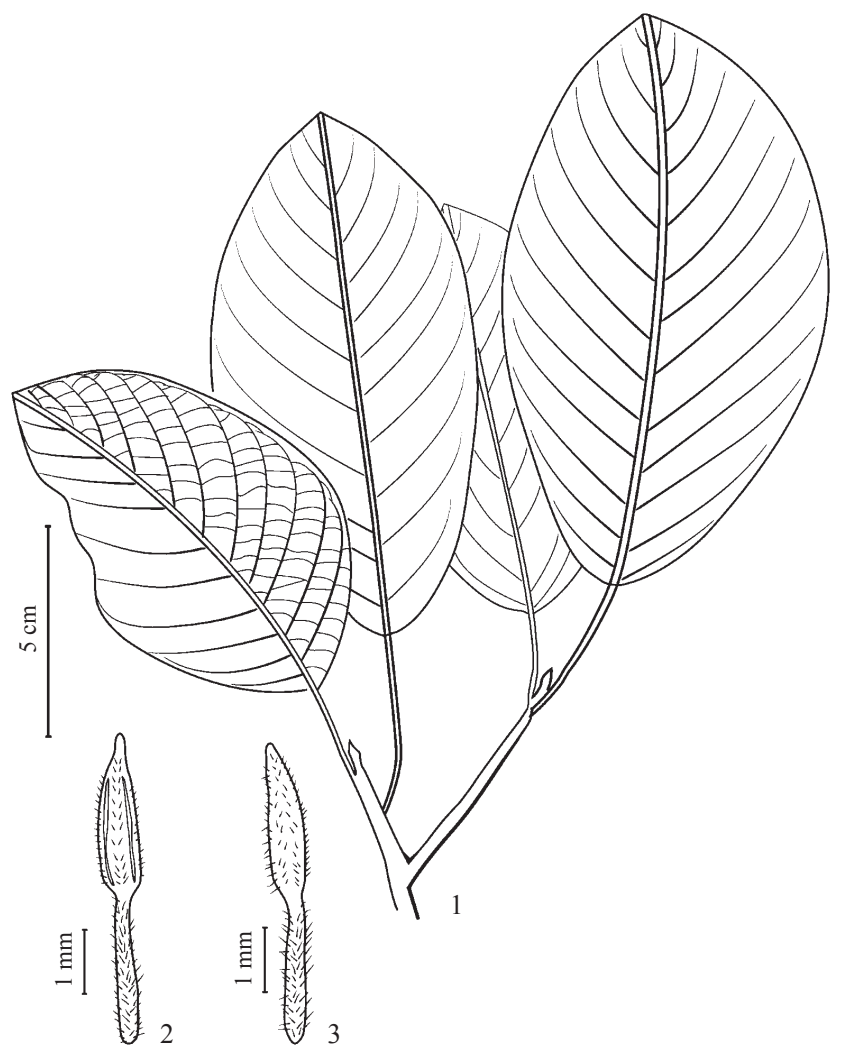

Figures 1-3. Sloanea dubia. 1. Branch. 2. Stamen, ventral view. 3. Stamen, dorsal view. (MR Mesquita, 19). 
of $S$. brachytepala open by lenticular pores that are $1 / 4$ of the total length of the anther, while in S. dubia the anther openings are longitudinal.

The known distribution of $S$. dubia is currently restricted to the Ducke Reserve, where it has been collected six times. Three of the collections had fruits during December, February, and March; the other three collections had flowers during October.

Sloanea pseudoverticillata Boeira sp. nov. Tipo: BRAZIL. Amazonas: Manaus, Reserva Florestal Ducke, 11-1995, JELS Ribeiro et al. 1765 (Holotype: INPA; Isotype: $\mathrm{K}, \mathrm{MO}$ ).

Figures 4-6

Species S. fendleriana similis, sed differt foliis ad apicem ramorum aggregatis, laminis foliorum in ambabus superficiebus pubescentibus, margine serratis, ad apicem retusis, venatione cladodromo; staminibus exterioribus antheris filamentis longioribus, eadem plus interioribus filamentis antheris longioribus.

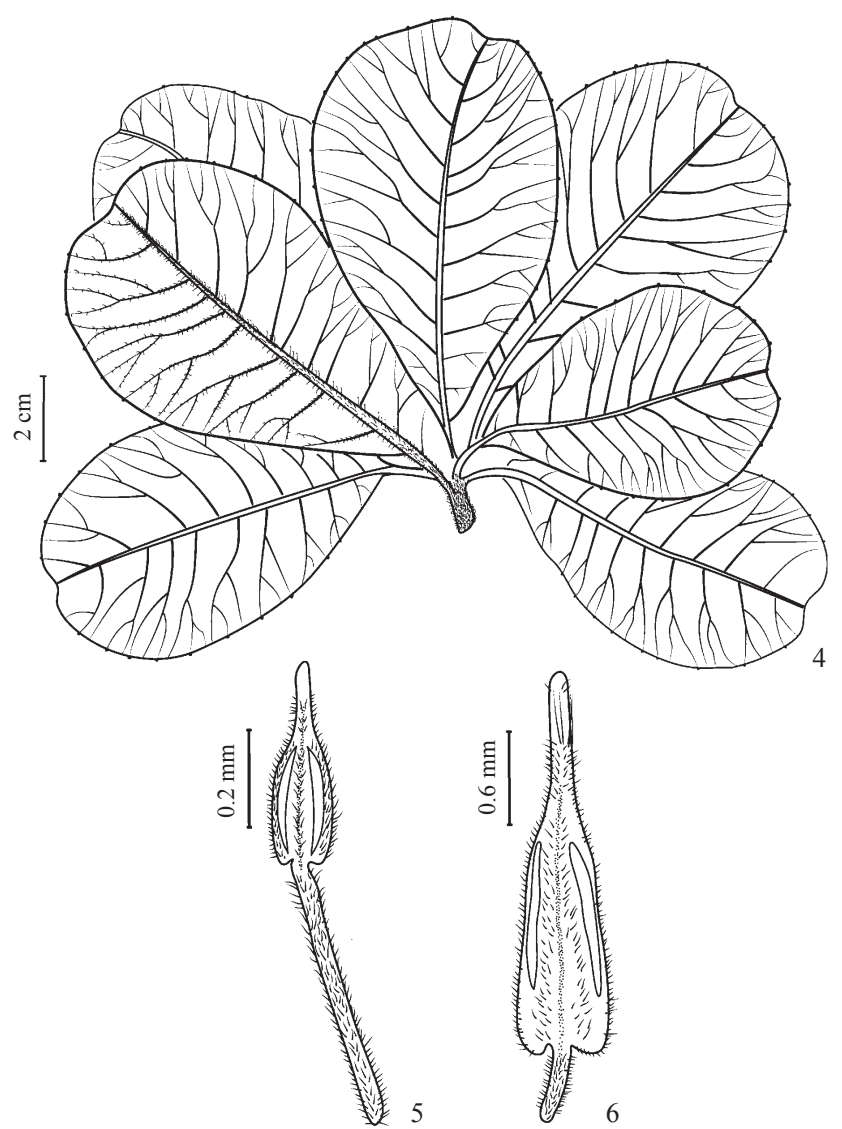

Figures 4-6. Sloanea pseudoverticillata. 4. Branch. 5. Stamen of the inner floral whorl, ventral view. 6. Stamen of the external floral whorl, ventral view. (JELS Ribeiro et al. 1765).
Tree $25 \mathrm{~m}$ tall, DBH $60 \mathrm{~cm}$; trunk cylindrical, with large tabular roots; live bark yellow, becoming darkorange; rhytidome horizontally striated. Leaves $(n=5)$ alternate, $8.5-(8.6 \pm 0.2)-8.8 \mathrm{~cm}$ long, grouped at the branch apex; stipules deciduous; petiole 0.9-(1.13 \pm 0.3$)$ $1.0 \mathrm{~cm}$ long, densely pubescent; blade obovate, 5.0 (5.5 \pm 3$)-6.0 \mathrm{~cm}$ wide, base decurrent, apex retuse, adaxial and abaxial faces sparsely pubescent, margins with some serration; secondary venation cladodromous, average of 12 pairs of secondary veins; tertiary mixedpercurrent. Midrib prominent above $(n=1)$, sparsely pubescent on adaxial and abaxial surfaces. Inflorescence axillar, $10.5-(12.5 \pm 1.7)-14 \mathrm{~cm}$ long, peduncle 89(96 \pm 5.2$)-101 \mathrm{~mm}$ long, pedicel 4.3-(5.9 \pm 1$)-6.9 \mathrm{~mm}$ long, width less than the receptacle. Flores 1-(5 \pm 1$)$ 11 per inflorescence; 4 tepals $4.5-(4.6 \pm 0.3)-5.0 \mathrm{~mm}$ long, 3.5-(3.5 \pm 0.2$)-4.0 \mathrm{~mm}$ wide at base; 120 stamens; staminoids absent; anther 1.5-(1.9 \pm 0.5$)-2.5 \mathrm{~mm}$ long, densely pubescent, longitudinally dehiscent; connective prolonged to a sharp point 0.2-(0.4 \pm 0.2$)-0.7 \mathrm{~mm}$ long, sparsely pubescent; filament $0.5-(1.8 \pm 1.5)-3.6 \mathrm{~mm}$ long, densely pubescent; ovary 2.1-(2.3 \pm 0.03$)-2.3 \mathrm{~mm}$ wide, densely pubescent; 4 locules; style 3.5-(4.2 \pm 0.7$)$ $5.0 \mathrm{~mm}$ long, entire. Fruits $1.2 \mathrm{~cm}$ long without spines. Occurs on clayish soils in the Ducke Reserve $(n=1)$.

Material examined: BRAZIL. AmAzonAs: Manaus, Reserva Florestal Ducke, 17-XI-1995, JELS Ribeiro et al. 1765 (INPA, K, MO).

Commentaries: The species most similar to $S$. pseudoverticillata is $S$. fendleriana, as both have leaves with very short (0.8-1.0 cm long) and pubescent petioles, with leaf blades obovate with entire margins (and can thus be distinguished from the other species of the genus). These two species, however, differ in terms of various vegetative and floral morphological characters. The first of these differences can be seen in the grouping of the leaves at the branch apex: they are not grouped in $S$. fendleriana, while the leaves of $S$. pseudoverticillata are so tightly grouped that they give the false impression of a verticillate type of phyllotaxis (this being the reason for the new specific epithet). Another very evident difference is in arched-ascendant nature of the secondary veins in S. fendleriana, as opposed to the craspedodromous type in S. pseudoverticillata. The leaf apex is obtuse to acute in $S$. fendleriana and retuse in $S$. pseudoverticillata. $S$. fendleriana has leaves with entire margins, while the leaf margins of $S$. pseudoverticillata are slightly serrated. $S$. fendleriana has a single type of stamen, while $S$. pseudoverticillata has two verticils of stamens, the outer whorl having filaments that are smaller than the anthers, and an internal whorl having filaments larger than the 
anthers. These morphological differences, together with the fact that both species occur in the Ducke Reserve, indicates that $S$. pseudoverticillata is a new species.

Sloanea heteroneura Boeira sp. nov.Tipo: BRAZIL. Amazonas: Manaus, Reserva Florestal Ducke, próxima ao bosque da castanha de galinha, OP Monteiro 39, I-1976 (INPA 54516)

Figures 7-8

Species S. synandra similis, a qua differt laminis apice retusis et basi lobatis, tepalis plus longis, dehiscentia longitudinali antherarum, filamentis longis trichomatibus obtectis et absentia staminodiorum.

Tree $15 \mathrm{~m}$ tall, DBH $30 \mathrm{~cm}$. Leaves $(n=3)$ alternate, 9-(9 \pm 1$)-11 \mathrm{~cm}$ long, not grouped at the branch apex; stipules deciduous; petiole 1.5-(1.8 \pm 0.1$)-2 \mathrm{~cm}$ long, densely pubescent; blade oval, 7.5-(78 \pm 2.5$)-8.0 \mathrm{~cm}$ wide, base lobate, apex retuse $(n=2)$, adaxial and abaxial faces sparsely pubescent, margins entire $(n=2)$; secondary venation brochidodromous, averaging 10 pairs of secondary veins; tertiary veins percurrent opposite. Midrib impressed above $(n=2)$, sparsely pubescent on the adaxial and abaxial surfaces. Inflorescence with the pedicel narrower than the receptacle. Flowers with 4 tepals, 3-(3 \pm 0$)-3 \mathrm{~mm}$ long, 3.0-(3.0 \pm 0$)-3.0 \mathrm{~mm}$ wide at base; staminoids absent; anther 0.8-(1.1 \pm 0.01$)-1 \mathrm{~mm}$ long, densely pubescent, longitudinally dehiscent; connective prolonged to a sharp point $0.3-(0.3 \pm 0.01)$ $0.3 \mathrm{~mm}$ long, densely pubescent; filament $0.8-(0.8 \pm 0.01)$

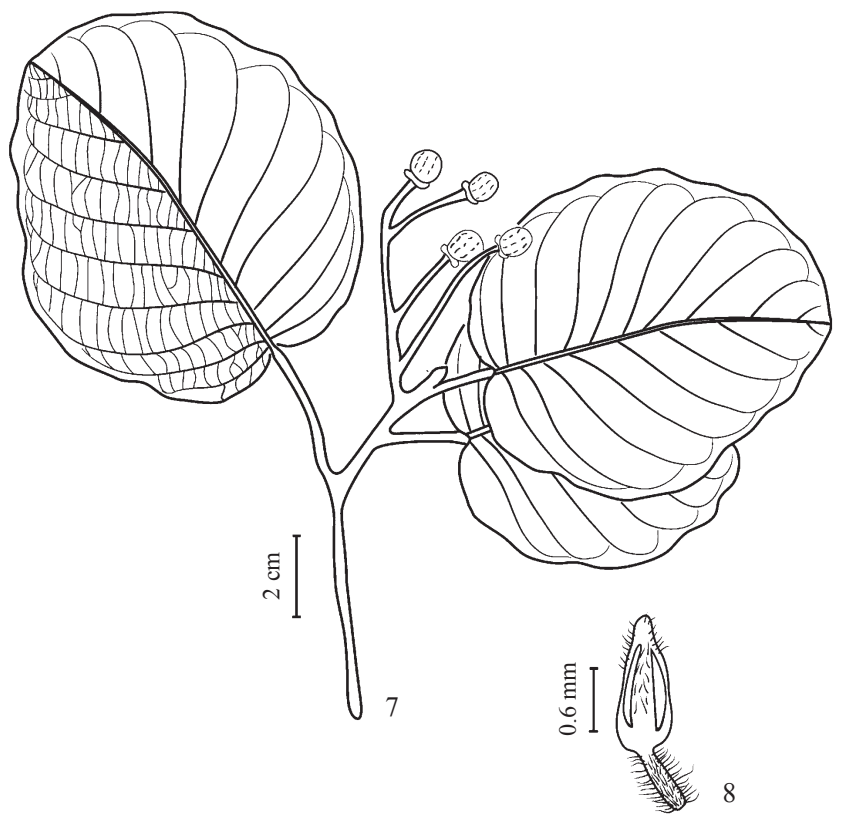

Figures 7-8. Slonea heteroneura. 7. Branch with fruits. 8. Stamen, ventral view. (OP Monteiro 39).
$0.8 \mathrm{~mm}$ long, 6-parted at apex, densely pubescent, trichomes long; ovary densely pubescent. Fruits known only immature, lacking spines. Occurs on clayish soils in the Ducke Reserve $(n=1)$.

Material examined: BRAZIL. AmAzonAs: Manaus, Reserva Florestal Ducke,12-X-1965, OP Monteiro 39 (INPA).

Commentaries: The herbarium collections of Sloanea heteroneura were examined by Castañeda (1981) who observed that this was possibly a new species and was very close to $S$. excelsa. This author did not comment on any similarities between the two species. This author did note, however, that $S$. heteroneura differed from $S$. excelsa in having oblonglanceolate anthers with rimose dehiscence, longpubescent filaments, and that the style was divided at the apex. However, we consider Sloanea heteroneura to be morphologically more similar to $S$. synandra, as both have ovate leaves, brochidodromous secondary venation, and percurrent opposite tertiary venation. These species are sympatric in the Ducke Reserve and can be otherwise easily distinguished: (1) the blade apex of $S$. heteroneura is retuse, while in $S$. synandra it is acute to short-acuminate; (2) the base of the blade in $S$. heteroneura is lobate, while in S. synandra it is rounded; (3) the tepals of $S$. heteroneura are approximately $3 \mathrm{~mm}$ long, while those of S. synandra are 13-20 mm long; (4) the anther openings of $S$. synandra are of the poricidal type, while those of $S$. heteroneura are longitudinal; and, (5), the flowers of $S$. synandra have staminoids while the flowers of $S$. heteroneura do not possess these structures. The characteristic that most defines $S$. heteroneura, however, are the sinuous secondary veins near the leaf base (figure 7) similar to the letter "S". This character was not observed in the other species of the genus and was therefore utilized in the species epithet (from the Greek, the prefix hetero = different; and the word neuron = venation).

Sloanea heteroneura is morphologically different from the other species of Sloanea described for the tropics as it is the only taxon that has the S-shaped secondary venation described above. Castañeda (1981) suggested that this species was most similar to $S$. excelsa, while our observations suggest its closest affinity with $S$. synandra. In any case, these three species are sympatric in the Ducke Reserve, where they are clearly distinct, indicating that $S$. heteroneura is in fact a new species. $S$. heteroneura is only known from the Ducke Reserve and was only collected once (with floral structures and fruits) during the month of October. It occurs on clayish soils. 
Acknowledgments - The authors thank the Graduate Program in Botany of the Instituto Nacional de Pesquisas da Amazônia - Inpa, Capes for the Masters study grant, Procad for financing the fieldwork, and Dr. William Antônio Rodrigues for assistance with botanical nomenclature and diagnoses.

\section{REFERENCES}

Boeira ASP. 2010. O gênero Sloanea L. (Elaeocarpaceae) na Reserva Florestal Adolpho Ducke. Dissertação de mestrado, Instituto Nacional de Pesquisas da Amazonia, Manaus

Castañeda MDA. 1981. Revisão taxonômica do gênero Sloanea Linnaeus (Elaeocarpaceae) na Amazônia Brasileira. Dissertação de mestrado, Fundação Universidade do Amazonas/Instituto Nacional de Pesquisas da Amazonia, Manaus.

Crayn DM, Rosseto M, Maynard DJ. 2006. Molecular Phylogeny and dating reveals an Oligo-Miocene radiation of dry-adapted shrubs (former Tremandraceae) from rainforest tree progenitors (Elaeocarpaceae) in Australia. American Journal of Botany 93:1328-1342.

Heywood VH. 2007. Flowering plants families of the world. Royal Botanic Gardens, Kew.
Leaf Architecture Working Group. 1999. Morphological description and categorization of dicotyledonous and netveined monocotyledonous angiosperms. Smithsonian Institution. Washington DC.

Oliveira AA, Daly DC. 1999. Geographic distribution of tree species occurring in the region of Manaus, Brazil: implications for regional diversity and conservation. Biodiversity and Conservation 8:1245-1259.

Ribeiro JELS, Hopkins MG, Vicentini A, Sothers CA, Costa MAS, Brito JM, Souza MAD, Martins LHP, Lohmann LG, Assunção PACL, Pereira EC, Silva CF, Mesquita MR, Procópio L. 1999. Flora da Reserva Ducke: Guia de identificação das plantas vasculares de uma floresta de terra-firme na Amazônia Central. Instituto Nacional de Pesquisas da Amazonia, Manaus.

Smith CE. 1954. The New World species of Sloanea (Elaeocarpaceae).Contributions from the Gray Herbarium of Harvard University 175:111-114.

Vicentini A. 1999. Elaeocarpaceae. In Flora da Reserva Ducke: Guia de identificação das plantas vasculares de uma floresta de terra-firme na Amazônia Central (JELS Ribeiro, MG Hopkins, A Vicentini, CA Sothers, MAS Costa, JM Brito, MAD Souza, LHP Martins, LG Lohmann, PACL Assunção, EC Pereira, CF Silva, MR Mesquita, Procópio L, eds.). Instituto Nacional de Pesquisas da Amazonia, Manaus, p.258-263. 